Діана Животівська, кандидат історичних наук, старший викладач кафедри теорї та методики професійної підготовки

ДВНЗ «Переяслав-Хмельницький державний педагогічний університет імені Григорія Сковороди».

E-mail: diana7454@ukr.net

ORCID 0000-0001-8113-6142

Diana Zhivotivska,

PhD in History, Senior Lecturer of the

Department of Theory and Methodology of

Vocational Training

SHEI «Pereiaslav-Khmelnytskyi

Hryhorii Skovoroda

State Pedagogical University».

\title{
ТЕОРЕТИЧНІ ОСНОВИ ФОРМУВАННЯ ДОСЛІДНИЦЬКИХ УМІНЬ У МАЙБУТНІХ ФАХІВЦІВ 3 ОХОРОНИ ПРАЦІ
}

У статті розглянуто теоретичні основи формування та розвитку дослідницьких умінь у майбутніх фахівців з охорони прачі. Дослідницька діяльність формує вміння для подальшого особистісно-професійного зростання компетентного фахівия. Визначено, щзо розв'язання системи творчих завдань та здійснення пошукової діяльності позитивно впливає на формування дослідницьких умінь студентів.

Науково-дослідницька діяльність студентів є засобом професійної підготовки майбутніх фахівиів. Вона актуалізує креативні можливості особистості в аспекті вироблення власного погляду на шляхи розв'язання проблемної виробничої ситуації, розвиває творче мислення, індивідуальні здібності, дослідницькі навички.

Розв'язання проблеми формування дослідницьких умінь потребує комплексного та системного підходу. Результативність процесу формування дослідницьких умінь зумовлюється його організацією.

Ключові слова: дослідницькі уміння, фахівці, охорона праці, професійна підготовка, дослідницькі завдання, дослідницька компетентність.

The article deals with the theoretical principles of formation and development of research skills in future specialists in labor protection. Research activity forms the ability for further personal and professional development of a competent specialist. It is determined that the positive influence on the formation of research skills of students is to involve students in solving the system of creative tasks and the pursuit of search activities aimed at understanding the students of their actions. The solution of creative tasks is one of the main elements of the formation of research skills.

Research activities of students are a means of training future professionals. It actualises creative possibilities of the individual in the aspect of developing his or her own point of view on the ways of solving the problematic production situation, develops creative thinking, individual abilities, research skills of students, allows for the training of initiative specialists, develops scientific intuition, depth of thinking, creative approach to the perception of knowledge and practical application in solving set tasks.

Solving the problem of developing research skills requires a comprehensive and systematic approach. The effectiveness of the formation of research skills is determined by its organization. At the first stage of the organization of teaching and research activities, the student teaches them to isolate the problem in a given situation. At the second stage of formation of students of research skills involves the use of research tasks. At the third stage of formation, students of research skills use research experimental tasks.

Among the pedagogical approaches that will contribute to the effective formation of the research skills of future specialists in labor protection, it is defined: personal, task and activity. hcompetence.

Keywords: research abilities, specialists, labour protection, professional preparation, research tasks, researc

Постановка проблеми. Процес підготовки студентів передбачає опанування майбутніми фахівцями комплексу знань та формування умінь, серед яких особливе місце займають дослідницькі.

У творчо-дослідницькій навчальній діяльності використовуються такі інтелектуальні здібності, як допитливість, здатність до розробки гіпотези, легкість 
генерування ідей, гнучкість думок, оригінальність мислення, вміння знаходити аналогії [Гловин, 2007: c. 45].

Аналіз останніх досліджень $\boldsymbol{i}$ публікацій. Питанням організації дослідницької діяльності студентів займалися науковці В. Андрєєв, Н. Амеліна, Б. Зиков, І. Каташинська, В. Литовченко та ін.

У своєму дослідженні А. Нізовцев наголошував, що формувати дослідницькі вміння у студента означає створювати такі умови для його дослідницької діяльності, за яких прогнозовані компоненти вмінь залучаються до діяльності та внутрішньо розвиваються 3 урахуванням набутого досвіду студента, його індивідуальності, здібностей і бажань [Нізовцев, 2010: c. 33].

Метою статmi є висвітлення теоретичних засад формування дослідницьких вмінь у майбутнього фахівця з охорони праці.

Виклад основного матеріалу. Дослідницькі вміння науковці тлумачать як сукупність систематизованих знань, умінь i навичок особистості, поглядів i переконань, які визначають готовність студента до творчого пошукового вирішення пізнавальних завдань.

Слід зазначити, що науково-дослідницька діяльність студентів є засобом професійної підготовки майбутніх фахівців, оскільки, з одного боку, передбачає розв'язання проблемних практичних ситуацій, а 3 іншого, - актуалізує креативні можливості особистості в аспекті вироблення власного погляду на шляхи виходу 3 проблемної виробничої ситуації. Це найбільш ефективний метод підготовки якісно нових фахівців у вищій школі. Науково-дослідницька діяльність студентів максимально розвиває творче мислення, індивідуальні здібності, дослідницькі навички студентів, дає можливість здійснювати підготовку ініціативних фахівців, розвиває наукову інтуїцію, глибину мислення, творчий підхід до сприйняття знань та їх практичне застосування у виконанні певних завдань [Дробиш, 2015: с. 635636].

Для залучення студентів до дослідницької діяльності необхідно стимулювати ïx до творчого виконання дослідницьких завдань. Таким чином не тільки краще засвоюються знання 3 певної дисципліни, а й розвивається нестандартне мислення, кмітливість, наполегливість та творчий підхід до цього процесу. Дослідницькі завдання спонукають студентів до самостійних пошуків різних варіантів рішення, висування припущень, гіпотез, цілеспрямованих спроб їх підтвердження, відкидання гіпотез, які не підтвердилися, і заміни іншими, до послідовного осмислення. Виявляючи, усвідомлюючи й виправляючи свої помилки у процесі виконання дослідницьких завдань, студенти навчаються самостійно мислити. У процесі формування умінь у виконанні дослідницької роботи викладач має розвинути творчі здібності майбутнього фахівця [Павлюк, 2016: с. 27-29].

У своєму дослідженні О. Рогозіна [Рогозіна, 2007] виділяє п'ять рівнів мотивації дослідницької діяльності та позитивного ставлення до виконання навчально-дослідницьких завдань.

Перший рівень - дуже низький, споглядальний. Студент не виявляє ініціативи до самостійних дій, пошуку пояснень та доведення фактів, явищ, які він спостерігає, та не прагне до самостійного вивчення додаткової літератури 3 проблеми. Студент має незначний інтерес до виконання нескладних дослідницьких завдань, бувають спроби самостійного пояснення досліджуваних фактів та явищ, нерідко вони самостійно встановлюють причинно-наслідковий зв'язок, спостерігається інтерес до вивчення додаткової літератури [Рогозіна, 2007: c. 48]. 
Другий рівень - низький, споглядально-діяльний. Студент має незначний інтерес до виконання нескладних дослідницьких завдань, бувають спроби самостійного пояснення досліджуваних фактів та явищ, нерідко вони самостійно встановлюють причинно-наслідковий зв'язок, спостерігається інтерес до вивчення додаткової літератури [Рогозіна, 2007: с. 48].

Третій рівень - середній, діяльнісний. Цьому рівню притаманний інтерес, бажання, прагнення до навчально-дослідницької діяльності. Позитивна мотивація студентів до дослідницької роботи, хоча й невисокого рівня, спостерігається періодично [Рогозіна, 2007: c. 49].

Четвертий рівень - високий, діяльнісно-дослідницький. Значно зростає інтерес та прагнення студента до дослідницької діяльності. Він прагне до вирішення проблемних питань, виконання дослідницьких завдань за власною ініціативою [Рогозіна, 2007: c. 49].

П'ятий рівень - дуже високий, дослідницький. У студентів цього рівня систематично та яскраво виражений інтерес до досліджень. Вони постійно виконують складні завдання науково-дослідницького спрямування. На цьому етапі можна говорити про сформованість стійкого дослідницького інтересу [Рогозіна, 2007: c. 49].

Мотиваційний компонент у структурі навчально-дослідницької діяльності покликаний виконувати такі функції: активізуючу, спрямовуючу, регулюючу [Рогозіна, 2007: c. 49].

У своїй дисертаційній роботі Н. Гловин [Гловин, 2007] аналізує такі групи дослідницьких вмінь:

- операційні дослідницькі, до яких відносять розумові прийоми й операції, що використовуються в дослідницькій діяльності: порівняння, аналіз і синтез, абстрагування та узагальнення, висунення гіпотези, співставлення;

- організаційні дослідницькі, що включають застосування прийомів організації в науково-дослідній діяльності, планування дослідної роботи, проведення самоаналізу, регуляцію власних дій у процесі дослідницької діяльності;

- практичні дослідницькі, що включають опрацювання літературних джерел, проведення експериментальних досліджень, співставлення фактів, подій та обробку даних спостережень, впровадження результатів у практичну діяльність;

- комунікативні дослідницькі, що передбачають застосування прийомів співробітництва в процесі дослідницької діяльності, для здійснення взаємодопомоги, взаємоконтролю [Гловин, 2007: с. 22-23].

На кожному занятті має відбуватися процес формування й розвиток дослідницьких умінь у студентів. Можливо навіть формувати дослідницькі вміння у процесі контролю знань та навичок студентів; під час тестування або виконання творчих завдань [Павлюк, 2016: с. 34].

Формування пошуково-дослідницьких умінь у процесі виконання завдань реалізується через такі уміння:

- пошуково-мобілізаційні: оперативно змінювати свої дії відповідно до навколишнього оточення;

- конструктивні: уміння проектувати навчальну ситуацію; уміння складати перспективні плани своєї діяльності, творчі програми і алгоритми дій для виконання 
системи педагогічних завдань; уміння планувати професійну діяльність 3 урахуванням умов іiі протікання;

- пошуково-інформаційні: уміння шукати й обробляти інформацію для іï подальшого використання; уміння обирати найраціональніші методи і способи обробки інформації; уміння використовувати інформацію залежно від умов іï застосування;

- аналітико-інтелектуальні: уміння усвідомлено уявляти педагогічні явища як систему, осмислювати кожен елемент системи 3 іншими елементами; уміння висувати гіпотези, формулювати докази, спростування, міркувати логічно й обгрунтовано; уміння слідувати алгоритму для вдосконалення певних розумових дій; уміння застосування здобутих знань з урахуванням характеру діяльності, яка здійснюється;

- прогностичні: уміння прогнозувати результати діяльності; уміння визначати близькі, середні й далекі перспективи в професійному становленні майбутніх фахівців; уміння розробляти плани конкретних професійно-орієнтованих ситуацій;

- дослідницько-творчі: уміння використовувати у своїй професійній діяльності імпровізацію; уміння прийняття неординарних рішень; уміння здійснювати психолого-педагогічне дослідження педагогічного процесу; уміння самостійно знаходити варіанти рішень;

- рефлексивні: аналізувати правильність поставлених цілей, конкретизація їх у завдання; уміння оцінювати завдання, що реалізуються; уміння аналізувати причини труднощів під час реалізації поставлених завдань;

- оцінні: уміння використовувати різноманітні методи оцінки професійної діяльності: уміння використовувати різноманітні форми контролю при здійсненні професійної діяльності [Кулешова, 2012: с. 58-60].

Автор роботи [Рогозіна, 2007] вказує, що важливою умовою забезпечення високого рівня дослідницької діяльності студентів $\epsilon$ етапність науководослідницьких завдань 3 урахуванням можливостей i досвіду пізнавальної діяльності. На першому етапі виконання дослідницьких завдань увага студентів акцентується на формуванні наукового аналізу, опануванні навичок рецензування, об'єктивної оцінки наукових джерел. Результати першого етапу можуть бути оформлені як огляд літератури з досліджуваної проблеми, доповідей, анотації. На другому етапі необхідно створити умови, за яких студент виконував би дослідницькі завдання 3 обраної теми. Виконання завдань дослідницького характеру сприяє розвитку творчих здібностей, розвитку потреби та бажання займатися дослідницькою діяльністю [Рогозіна, 2007: с. 63].

Важливою умовою формування дослідницьких умінь $є$ чіткість мети й етапів роботи, яку необхідно виконати. Ступінь сформованості дослідницьких умінь у студентів буде визначатися тим, як викладач допоможе їм усвідомити необхідність та значущість цієї діяльності в їх професійному виборі. Викладач має обгрунтувати завдання для дослідницької діяльності [Рогозіна, 2007: с. 64].

Велике значення в системі підготовки майбутніх фахівців 3 охорони праці мають лекції, практичні заняття, консультації, курсові та дипломні проекти.

На лекційних заняттях потрібно враховувати особливості аудиторії, місце, час проведення. Правильно поставлені завдання $€$ основним фактором впливу при формуванні дослідницьких умінь студентів [Павлюк, 2016: с. 35]. 
Завершальним етапом вивчення дисципліни $є$ заключна лекція, на якій підбивають підсумки, розповідають про тенденції розвитку відповідної галузі знань, зосереджують увагу студентів на практичному використанні засвоєних ними знань як у подальшій навчальній роботі, так і в професійній діяльності [Павлюк, 2016: c. 36].

Практичні заняття теж формують у студентів навички дослідницької роботи, оскільки на практичних заняттях використовуються різні методи навчання.

Для заохочення студентів до дослідницької діяльності практичні заняття повинні:

- давати базові теоретичні знання;

- виробляти вміння й навички, які мають професійну спрямованість;

- забезпечувати умови для формування умінь і навичок;

- навчати студентів раціональним методам застосування вмінь і навичок;

- заохочувати самостійність у діяльності студента;

- витримувати систематичність та послідовність у формуванні умінь та навичок студентів;

- розробляти завдання з чіткою професійною спрямованістю;

- включати в систему практичних занять завдання творчого характеру;

- контролювати виконання студентами практичних завдань;

- заохочувати студентів до практичної діяльності [Павлюк, 2016: c. 44-45].

3 точки зору дослідницької діяльності консультація дає можливість студентові впевнитися в собі, у своїх результатах, а також за завданням викладача зайнятися певним видом діяльності. За спрямованістю іï необхідно скеровувати на допомогу студентам в оволодінні методологією теми або розділу, а також методами самостійної навчальної роботи [Павлюк, 2016: с. 47].

При підготовці майбутніх фахівців з охорони праці велику увагу приділяють виконанню курсових та дипломних проектів. Вони передбачають систематизацію та закріплення теоретичних і практичних знань зі спеціальності, а також розвиток навичок самостійної роботи.

Одним $з$ елементів дослідницької діяльності студентів $є$ експеримент, який забезпечує науково-об'єктивну й доведену перевірку правильності раніше обгрунтованої гіпотези i дає можливість глибше перевірити ефективність розроблених алгоритмів виконання завдань, вибрати їх оптимальне сполучення та виявити необхідні умови розв’язання дослідницьких задач. Експеримент $\epsilon$ комплексом методів дослідження.

Ефективність формування навчальних дослідницьких умінь та навичок у студентів залежить від умілого використання викладачем різноманітних форм, методів, засобів навчання й забезпечує раціональне чергування репродуктивного, пояснювально-ілюстративного, частково-пошукового та дослідницького методів; раціональне співвідношення фронтальної, групової та індивідуальної форм роботи 3 урахуванням диференціації навчання; органічне поєднання традиційних і сучасних засобів навчання [Павлюк, 2016: с. 141].

Висновки. Важливою умовою формування дослідницької компетентності студентів є організація їх активної навчально-дослідницької діяльності. Доведено, що формування дослідницької компетентності ефективно відбувається в процесі виконання дослідницьких завдань. Серед педагогічних підходів, які сприятимуть 
ефективному формуванню дослідницьких умінь майбутніх фахівців з охорони праці визначено: особистісний, задачний та діяльнісний.

\section{ЛІТЕРАТУРА}

Гловин, 2007 - Гловин Н. М. Формування дослідницьких умінь 3 дисциплін природничо-математичного циклу в студентів агротехнічного інституту в процесі фахової підготовки : дис... канд. пед. наук: 13.00.04 / Тернопільський національний педагогічний ун-т ім. Володимира Гнатюка. Тернопіль, 2007. 207 с.

Дробиш, 2015 - Дробиш Л. В., Карпенко Ю. В. Дослідницька діяльність студентів як засіб якісної підготовки фахівців. Проблеми формування та розвитку інноваційної інфраструктури: європейський вектор нові виклики та можливості [Електронний ресурс] : тези доповідей III Міжнародної науковопрактичної конференції, 14-16 травня 2015 р. Львів : Видавництво Львівської політехніки, 2015. С. 635-636.

Кулешова, 2012 - Кулешова В. В., Мальована В. В. Методика формування пошуково-дослідницьких умінь майбутніх інженерів-педагогів у процесі професійної підготовки : монографія. Артемівськ : ННППІ УІПА, 2012. $264 \mathrm{c}$.

Нізовцев, 2010 - Нізовцев А. В. Формування дослідницьких умінь студентів технічних університетів у процесі вивчення професійно-орієнтованих дисциплін : дис. .... канд. пед. наук : 13.00 .04 / Полтав. нац. пед. унт ім. В. Г. Короленка. Полтава, 2010. 267 с.

Павлюк, 2016 - Павлюк Л. В., Пригодій М. А. Теоретико-практичні аспекти формування дослідницьких умінь у майбутніх бакалаврів енергетики агропромислового виробництва : монографія. Київ : Компринт, 2016. $274 \mathrm{c}$.

Рогозіна, 2007 - Рогозіна О. В. Формування дослідницьких умінь у майбутніх учителів трудового навчання : дис... канд. пед. наук: 13.00.02 / Національний педагогічний ун-т ім. М. П. Драгоманова. Київ, 2007. $218 \mathrm{c}$.

\section{REFERENCES}

Hlovyn, 2007 - Hlovyn N. M. Formuvannia doslidnytskykh umin z dystsyplin pryrodnycho-matematychnoho tsyklu v studentiv ahrotekhnichnoho instytutu v protsesi fakhovoi pidhotovky : dys... kand. ped. nauk: 13.00.04 / Ternopilskyi natsionalnyi pedahohichnyi un-t im. Volodymyra Hnatiuka. Ternopil, 2007. 207 s.

Drobysh, 2015 - Drobysh L. V., Karpenko Yu. V. Doslidnytska diialnist studentiv yak zasib yakisnoi pidhotovky fakhivtsiv. Problemy formuvannia ta rozvytku innovatsiinoi infrastruktury: yevropeiskyi vektor - novi vyklyky ta mozhlyvosti [Elektronnyi resurs] : tezy dopovidei III Mizhnarodnoi naukovo-praktychnoi konferentsii, 14-16 travnia 2015 r. Lviv : Vydavnytstvo Lvivskoi politekhniky, 2015. S. 635-636.

Kuleshova, 2012 - Kuleshova V. V., Malovana V. V. Metodyka formuvannia poshukovo-doslidnytskykh umin maibutnikh inzheneriv-pedahohiv u protsesi profesiinoi pidhotovky : monohrafiia. Artemivsk : NNPPI UIPA, 2012. $264 \mathrm{~s}$.

Nizovtsev, 2010 - Nizovtsev A. V. Formuvannia doslidnytskykh umin studentiv tekhnichnykh universytetiv u protsesi vyvchennia profesiino-oriientovanykh dystsyplin : dys. ... kand. ped. nauk : 13.00.04 / Poltav. nats. ped. un -t im. V. H. Korolenka. Poltava, 2010. 267 s.

Pavliuk, 2016 - Pavliuk L. V., Pryhodii M. A. Teoretyko-praktychni aspekty formuvannia doslidnytskykh umin u maibutnikh bakalavriv enerhetyky ahropromyslovoho vyrobnytstva : monohrafiia. Kyiv : Komprynt, 2016. $274 \mathrm{~s}$.

Rohozina, 2007 - Rohozina O. V. Formuvannia doslidnytskykh umin u maibutnikh uchyteliv trudovoho navchannia : dys... kand. ped. nauk: 13.00.02 / Natsionalnyi pedahohichnyi un-t im. M. P. Drahomanova. Kyiv, 2007. 218 s. 